\title{
3. OPEN-OCEAN TO TRENCH TURBIDITY-CURRENT FLOW IN THE NANKAI TROUGH: FLOW COLLAPSE AND FLOW REFLECTION ${ }^{1}$
}

\author{
Kevin T. Pickering, ${ }^{2}$ Michael B. Underwood, ${ }^{3}$ and Asahiko Taira ${ }^{4}$
}

\begin{abstract}
The Ocean Drilling Program Leg 131, which drilled in the Nankai Trough in the western Pacific Ocean, has shown for the first time that turbidity currents are deflected and reflected against the trench slopes, such that in the trench outer slope there is a predominant pattern of currents, carrying terrigenous sediments, apparently coming from the open-ocean Shikoku Basin directly toward the trench landward-slope. The purpose of this paper is to summarize the evidence for flow rebound at ODP Leg 131 Site 808, and to show that these results have important implications for the interpretation of paleocurrents in ancient linear turbidite systems.
\end{abstract}

\section{INTRODUCTION}

The deflection and reflection of turbidity currents have been invoked to explain deposits in modern and ancient deep-marine basins (van Andel and Komar, 1969; Pickering and Hiscott, 1985), and also experimentally modeled in flume tanks (Pantin and Leeder, 1987; unpubl. $\mathrm{PhD}$ thesis by Edwards, 1991). Upslope turbidity current flow has been proposed as a mechanism by which anomalously coarsegrained sediments came to rest on the Ceara Rise, western equatorial Atlantic (Damuth and Embley, 1979), the northern flanks of the Mediterranean Ridge (Cita et al., 1984), Tiburon Rise near the toe of the Barbados accretionary prism (Dolan et al., 1989), the outer slope of the Middle America Trench (Moore et al., 1982), and on the seaward slope of the Aleutian Trench (Underwood, 1991). Solitary or soliton wave theory appears to provide a reasonable theoretical explanation for the physical nature of at least some reflected turbidity currents (Pantin and Leeder, 1987; Edwards, 1991).

To date, some experimental work has been conducted in order to investigate the relationship between run-up elevation of turbidity currents on a given gradient. Empirical laboratory results suggest, for an energy loss of $33 \%$ caused by friction, the maximum run-up elevation of a flow on a $28^{\circ}$ slope (a steep slope in deep water environments) is equal to $1.53 \mathrm{~h}$, where $\mathrm{h}=$ thickness of the turbidity current (Muck and Underwood, 1990). Muck and Underwood (1990) stressed that this empirical relationship between run-up height and flow thickness should be viewed only as a first-order approximation. A growing information base of circumstantial, theoretical, and laboratory data support the contention that turbidity currents can be deflected or reflected at submarine barriers. Until ODP Leg 131, however, no direct current or paleocurrent measurements from a modern deep-marine basin were available to lend credence to the arguments for flow reflection and deflection.

\section{STUDY AREA AND TRENCH STRATIGRAPHY}

ODP Leg 131 drilled through the toe of the Nankai accretionary prism at Site 808 (Fig. 1) to recover a very complete stratigraphy down

\footnotetext{
${ }^{1}$ Hill, I.A., Taira, A., Firth, JV., et al., 1993. Proc. ODP, Sci. Results, 131: College Station, TX (Ocean Drilling Program).

${ }^{2}$ Department of Geology, University of Leicester, Leicester LEI 7RH, United Kingdom.

${ }^{3}$ Department of Geological Sciences, University of Missouri, Columbia, MO 65211, U.S.A.

${ }^{4}$ Ocean Research Institute, University of Tokyo, 1-15-1 Minamidai, Nakano-ku, Tokyo 164, Japan.
}

to the subducting basaltic oceanic crust (Fig. 2). In the vicinity of Site 808 , the Nankai Trough is about $14 \mathrm{~km}$ wide, and underlain by the northward-subducting approximately 14-Ma Shikoku Basin oceanic crust, with a relative plate motion of $4 \mathrm{~cm} \mathrm{a}^{-1}$, estimated from the seismic slip vectors, to $2 \mathrm{~cm} \mathrm{a}^{-1}$, as estimated from the age of the trench wedge (arguments in Taira, Hill, Firth, et al., 1991, p. 5).

\section{SITE 808 LITHOSTRATIGRAPHIC UNITS}

The lithology recovered at Site 808 (Holes A, B, and C) comprises six discrete lithological units, three of which contain subunits defined on the basis of visual core descriptions, grain size, bed/layer thickness, and mineralogy. The following lithological units are defined, from top to bottom of Site 808 (Fig. 2):

1. Unit I: Lower slope apron (0-19.15 mbsf);

2. Unit II: Trench-fill deposits (19.15-556.8 mbsf);

3. Unit IIa: Upper axial trench sandy deposits (19.15-120.6 mbsf);

4. Unit IIb: Lower axial trench silty deposits (120.6-263.4 mbsf $)$;

5. Unit IIc: Trench outer slope deposits (409.54-556.8 mbsf);

6. Unit III: Trench-basin transitional deposits (556.8-618.47 mbsf);

7. Unit IVa: Upper Shikoku Basin deposits (618.47-823.74 mbsf);

8. Unit IVb: Lower Shikoku Basin deposits (823.74-1243 mbsf);

9. Unit V: Silicic volcaniclastic deposits (1243-1289.9 mbsf);

10. Unit VI: Basaltic basement (1289.9-1318.82 mbsf).

* The interval $263.4-409.54 \mathrm{mbsf}$ is duplicated by the main frontal thrust in the toe region of the accretionary prism; the stratigraphic correlation and offset being defined by the repetition of the top of a unique matrix-supported mudstone-pebble conglomerate (Pleistocene NN20), giving a vertical offset of $145 \mathrm{~m}$. The conglomerate probably represents a debris-flow deposit (debrite) associated with the floor of the trench and appears as a prominent seismic reflector even below the present-day trench floor.

The characteristic sediments within these units are as follows: Unit I, sediment slides, silts, fine sands; Unit IIa, sands; Unit IIlb, thin sands + silts; Unit IIc, silts; Unit III, silts + mud + ash; Unit IVa, ash/tuff-rich (calcite high); Unit IVb, rare preserved discrete ash/tuff layers; Unit V, silicic volcaniclastics; and Unit VI, basaltic sills, sediment and basaltic basement.

Deposition upon a subducting plate of oceanic crust typically generates an overall coarsening-upward sequence from basaltic basement to open-ocean pelagic and hemipelagic sediments, then to the silty and sandy trench-fill turbidites (Piper et al., 1973; Taira and Niitsuma, 1986), something that is exemplified at Site 808 (Fig. 2; 


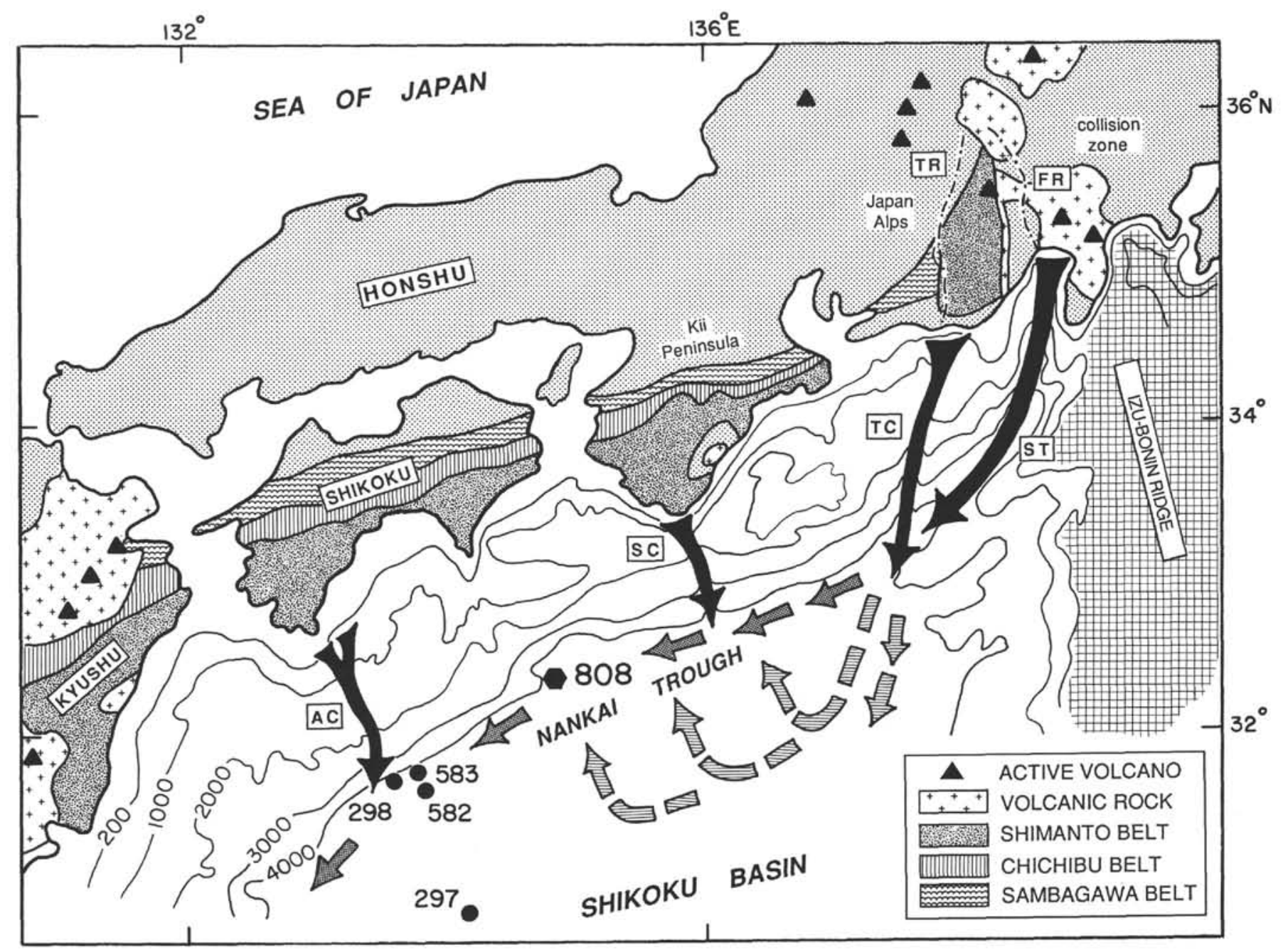

Figure 1. Location map of ODP Site 808 and neighboring DSDP Legs 37 and 87A sites, Nankai Trough. Major sediment entry points are as follows: ST = Suruga Trough, $\mathrm{TC}=$ Tenryu Canyon, $\mathrm{SC}=$ Shiono-misaki Canyon, $\mathrm{AC}=$ Ashizuri Canyon. Bathymetric contours are in meters. FR = Fuji River; TR = Tenryu River. Regions of volcanic rocks include Neogene-Quaternary mafic-intermediate to felsic composition.

Shipboard Scientific Party, 1991). The sediments that are being transported on the subducting slab toward the deformation zone comprise an upper terrigenous turbiditic unit and a lower hemipelagic (Shikoku Basin) unit, with locally abundant tuff layers.

The plate position of the basin-to-trench transition in terms of sediment grain size and depositional processes, rather than crustal or basinal morphology, is determined by factors such as the trench shape and dimensions relative to the rates of sediment supply, and changes in relative sea level at the points of sediment supply.

In trenches with a clear morphological depression, possibly including an axial channel, the characteristic sediments tend to be sandy turbidites in the trench axis, with silty turbidites in the trench outer slope and progressively muddier hemipelagic/pelagic sediments of the open-ocean seafloor. The Miocene-Holocene history of the Nankai Trough, south of the island of Shikoku, conforms to just such a depositional pattern (Fig. 2).

This paper focuses in on unusual, thin- to medium-bedded, finegrained sandy to silty turbidites recovered from the Pleistocene trench outer slope facies (Fig. 2). The trench outer slope facies at Site 808 (Unit IIc) was defined to begin immediately below a distinctive matrix-supported mudstone-pebble conglomerate, down to the first occurrence of a thick tuff (Fig. 2). Unit IIc contrasts with the overlying axial trench deposits in containing virtually no sand. Moreover, there are very few ash/tuff layers relative to the underlying trench to
Shikoku Basin transitional deposits. The stratigraphic position of Unit IIc, between deposits interpreted as trench-fill (Units IIa and IIb) and basin-trench transitional deposits (Unit III), is consistent with a trench outer slope environment. The present trench outer slope near Site 808 is about $10 \mathrm{~km}$ wide and has a northwest-inclined slope of only $0.38^{\circ}$, and the relief between the trench axis and top of the trench outer slope is approximately $50 \mathrm{~m}$. The trench floor width in this area is about 14 $\mathrm{km}$. The absence of terrigenous sandy turbidites in the Shikoku Basin sediments at Site 808 suggests that the trench topography was sufficient to contain the sandy part of turbidity currents that flowed down the Nankai Trough, at least oceanward of this site. Farther up- or downtrench, turbidity currents carrying terrigenous material may have spilled into the eastern or western parts of the Shikoku Basin away from the subducting spreading center which would have been a topographic high.

The Pleistocene sediments of the Nankai Trough were deposited by various sediment gravity-flow processes, such as turbidity currents, debris flows, and sediment slides. Data from DSDP Legs 31 and 87 (Taira and Niitsuma, 1986), together with recent results from ODP Leg 131 (Shipboard Scientific Party, 1991) near the surface expression of the frontal thrust in the Nankai accretionary prism, suggest that within Nankai Trough, axial flows from the Izu Collision Zone provide most of the sandy, and probably silty, turbidites in the trench. Large-scale sediment slides rework uplifted accreted sedi- 


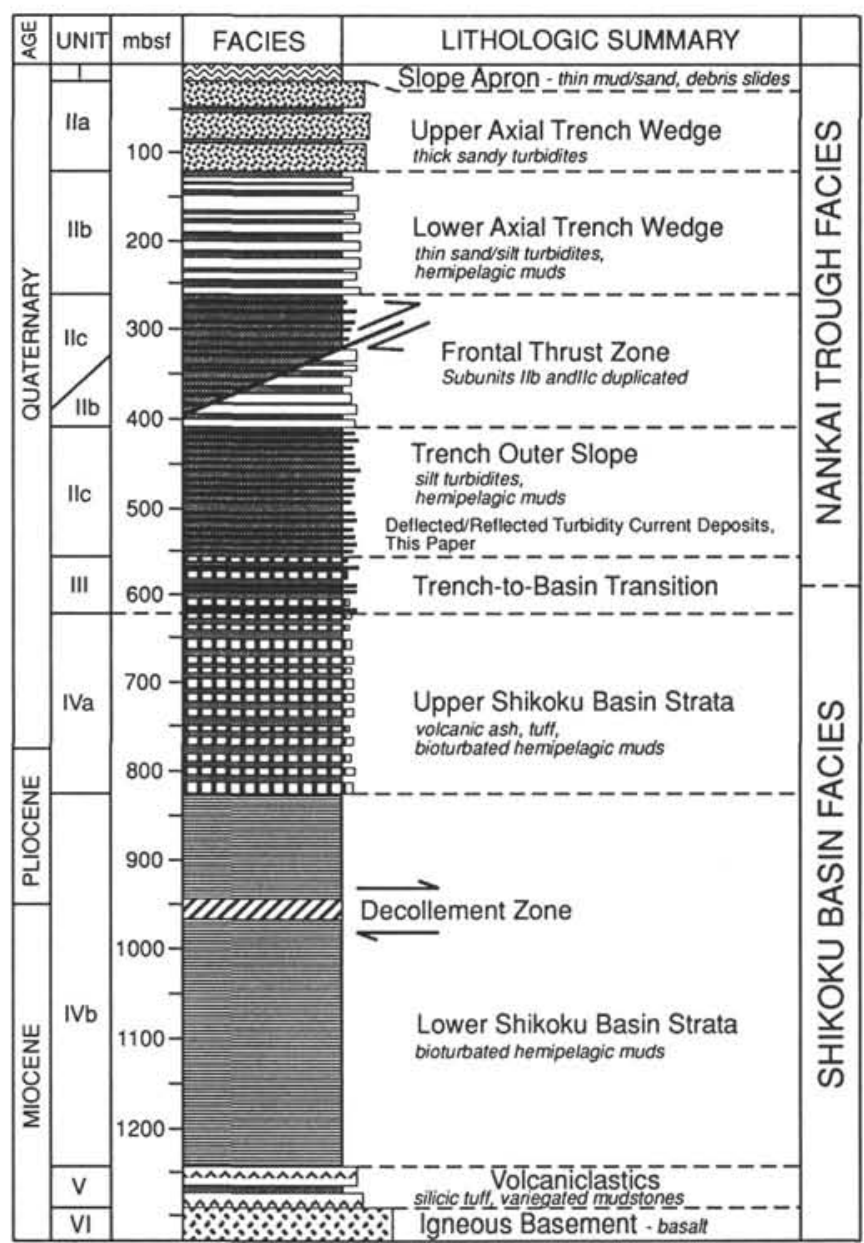

Figure 2. Summary stratigraphy of ODP Leg 131 Site 808 showing classic coarsening-upward sequence from open-ocean basin plain pelagic-hemipelagic mudstones to trench-fill sandy turbidites. Pleistocene trench outer slope turbidite section, focus of this paper, is shown as Unit IIc. Mbsf $=$ meters below seafloor.

ments down the lower landward slope of the trench and provide lateral supply. Such recycling and cannibalization of trench sediments gives a low preservation potential to the shallowly buried slope sediments of the prism.

The trench outer slope facies contains a distinct suite of fine sand and silty turbidites with current ripples. By restoring the dip azimuths to their original directions, using paleomagnetism, it becomes clear that paleoflow in the outer trench environment was variable and complex.

\section{FINE-GRAINED TURBIDITES}

The major lithologies of Unit IIc are thoroughly bioturbated (mottled) muds, with interbedded normally-graded, thin- to mediumbedded very fine-grained sandstones and coarse-grained siltstones showing Bouma $T_{c d e}$ divisions (Fig. 3). The ripple-laminated $T_{c}$ division is particularly common. A large variety of ichnogenera occur, including abundant Zoophycos. The proportion of silty turbidites to the clayey siltstone/silty claystone lithologies was estimated at $30 \%-$ 40\% (Shipboard Scientific Party, 1991).

The turbidites typically display a complex vertical structure (Fig. 3 ). The beds are essentially bipartite, with a lower laminated part overlain by a diffusely-laminated to structureless mud cap up to decimeters in thickness. Bioturbation, if present within these beds, generally is weak to moderate, and commonly as Chondrites. In contrast, the surrounding muds are thoroughly bioturbated. The absence of pervasive burrowing suggests rapid deposition of the mud cap, probably by flocculation from the tail of a turbidity current, rather than from a nepheloid layer.

The laminated siltstones show an overall vertical grading from a coarser erosive base of very fine sandstone to a silty mudstone cap. The basal sands tend to show repeated current-ripple divisions, rarely as climbing-ripple lamination. Rarely, the ripples show opposing flow directions within the same bed (Fig. 3A). The individual rippled zones are separated by parallel lamination. The current ripples invariably show stoss-side erosion and only lee-side preservation, indicative of a traction-dominated bedform. Convolute laminae and oversteepened lee faces to ripples occur in some beds. Grain-size breaks are represented by mudstone divisions up to $1 \mathrm{~cm}$ thick, but generally on a millimeter scale. Very low-angle to wavy lamination is common within some of these beds.

Within the cores, the base of a typical turbidite bed appears sharp and planar, and the bases are overlain either by parallel lamination or current ripples. The lowest layers of current ripples, if present, may be slightly coarser grained than the overlying laminae. Significantly, the avalanche faces of the ripples dip in various directions, even within a single turbidite bed. This variation in azimuthal direction for the laminae may be because the bedforms are linguoid ripples, but the occurrence of ripple-laminae with diametrically opposing lee-surface dip directions in a single bed, the grain-size breaks and the non-bioturbated, relatively thick, silty mudstone caps support an alternative, more complex, interpretation (this paper).

Many beds are underlain (less than $0.5 \mathrm{~cm}$ below) by blebs of sand up to about 1 phi coarser (i.e., fine sand) than the apparent base to the bed and apparently enclosed within the underlying mudstone. Such blebs were not recognized elsewhere in the sections. In some cases, the blebs lie directly beneath an erosive base, and are overlain by current-ripple lamination. The blebs of sand appear to represent load structures that detached from the cohesionless sediment above and partially sank into the soupy seafloor or sections through the edge of load structures. If the sand blebs are load structures, then there is a clear grain-size break between the loaded sand and the overlying sand/silt layers.

\section{PALEOCURRENT ANALYSIS USING NRM}

The flow vectors for the current ripples were measured by examining the uncut and cut faces of the same three-dimensional core (Table 1). In core, the ripples do not appear to be highly three-dimensional and the ripple azimuths are regarded as reasonable measurements of the flow direction.

The natural (detrital) remanent magnetism (NRM) was then used to restore the paleocurrents to their true flow directions based on the azimuthal dips of the lee faces of current-ripple laminations (Table 1). The primary orientation of the ripple lee faces was interpreted using the following assumptions: (1) the samples contain a measurable and stable component of remanence acquired parallel to the direction of the Earth's magnetic field at a known time; (2) corrections were made for any tectonic modification (e.g., bedding dip) of the remanence direction subsequent to remanence acquisition, which for the beds described in this paper was less than a few degrees, and (3) that the direction of the paleofield in which the remanence was acquired is known. In practice, this assumption requires an appeal to an axial geocentric dipolar model of the Earth's magnetic field with a known virtual pole position, and that the time interval represented by the sample is sufficiently long for secular variation to be averaged out. The sediments and rocks encountered at Site 808 are young enough for the Earth's magnetic field to be modeled satisfactorily by a dipole aligned along geographic north-south axis, and secular variations will be averaged out for the beds discussed in this paper. The reliability of the NRM compass was thoroughly tested through 
A
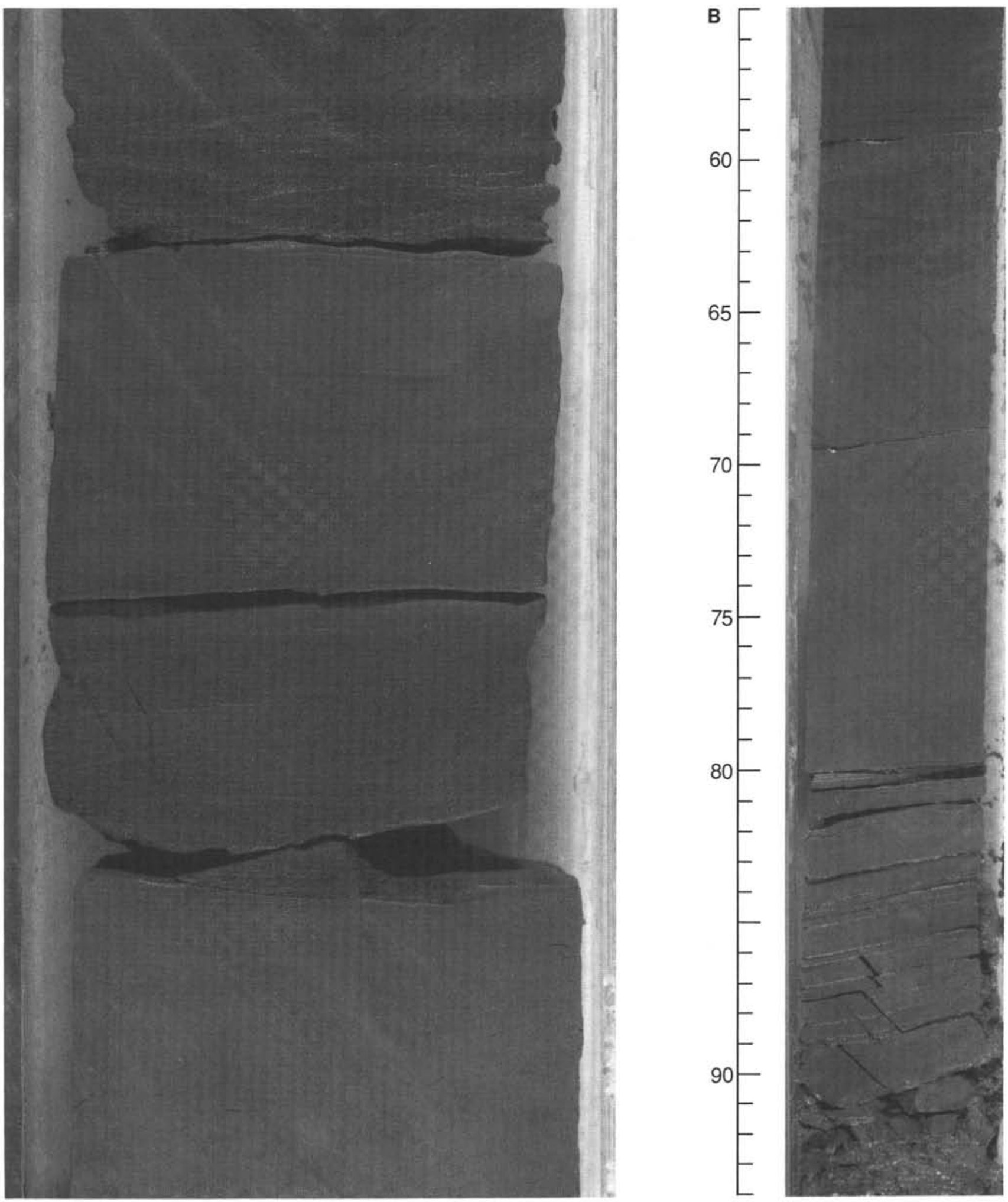

Figure 3. Core photographs of turbidite beds from the trench outer slope. These plates are representative of the sands, silts, and silty muds deposited within the outer trench marginal slope, some of which suggest flow reversals and flow deflections during deposition. A. Turbidite showing opposing flow directions in basal, fine-grained sand, ripple division of bed (arrows indicate dip azimuth of ripple laminae). Note the mud drapes within the $\mathrm{T}_{\mathrm{c}}$ division. The overlying silt and silty mudstone is laminated and shows little signs of bioturbation, in contrast to the same facies in surrounding intervals that lack these unusual turbidites. This suggests reversing (reflecting) turbidity currents during the development of the $T_{c}$ division and the relatively rapid deposition of the $T_{d e}$ divisions to hinder extensive downward bioturbation. B. Graded laminated, $\mathrm{T}_{\mathrm{de}}$ turbidite showing mottled, bioturbated, upper part (toward top of plate). Note the dark-colored post-depositional deformation bands in diffusely laminated to structureless upper part of bed and spaced fractures with similar orientation in sandy part of bed. C. Compound graded Bouma $T_{\text {cde }}$ turbidite with grain-size breaks between ripple divisions (see $\mathbf{D}$ for close-up). D. Close-up of compound graded Bouma $\mathrm{T}_{\text {cde }}$ turbidite with grain-size breaks between ripple divisions. Note bleb of slightly coarser grained sand at base of bed and climbing ripples toward top of photograph. 

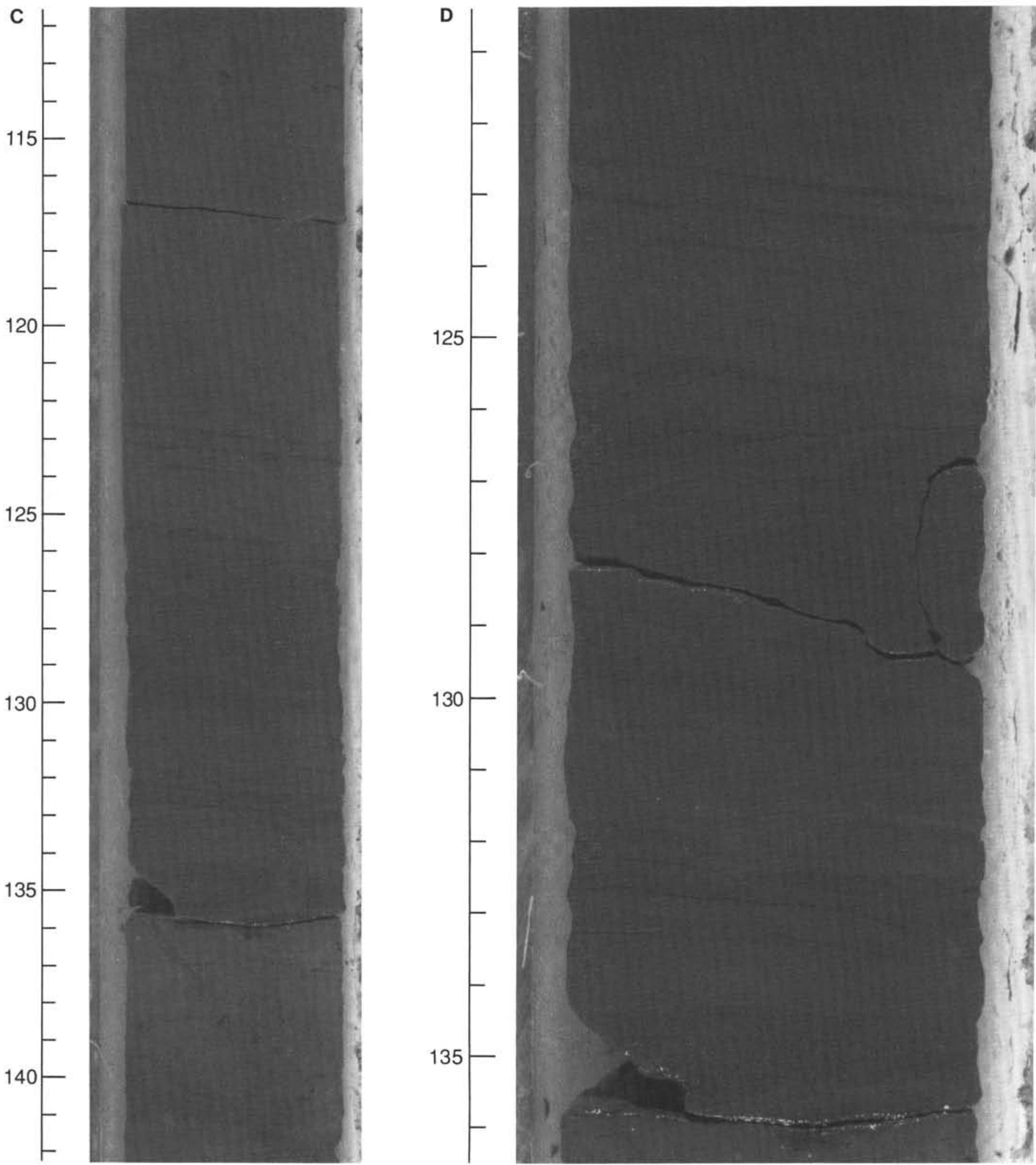

Figure 3 (continued).

structural fabric studies on Leg 131, thus the ripple orientation data can be considered as reliable (see p. 126-128 in Taira, Hill, Firth, et al., 1991).

Figure 4 shows a rose diagram for 44 individual current-ripple divisions, restored to their original dip directions (Table 1), with a maximum error bar of about $\pm 10^{\circ}$. These data represent the first such paleocurrent diagram in the entire DSDP/ODP history since its inception in 1968. The data show three principal flow directions: (1) down the trench outer slope and toward the north-northwest and the accretionary prism; (2) up the trench outer slope toward the south-southeast and the Shikoku Basin, and (3) toward the west-southwest along the trench axis from the Izu Collision Zone. 
Table 1. Paleocurrent data for current ripples from the trench outer slope, Site 808.

\begin{tabular}{|c|c|c|c|c|c|c|}
\hline Structure & $\begin{array}{c}\text { Core, section, } \\
\text { depth interval (cm) }\end{array}$ & $\begin{array}{l}\text { Depth } \\
\text { (mbsf) }\end{array}$ & Measvector ${ }^{a}$ & Palvector $^{\mathrm{b}}$ & $\begin{array}{l}\text { Declination }^{c} \\
\text { (degrees) }\end{array}$ & VectorCorr $^{d}$ \\
\hline & $131-808 \mathrm{C}$ & & & & & \\
\hline Ripple & $4 \mathrm{R}-1,47$ & 327.67 & 250 & 70 & 270 & 160 \\
\hline Ripple & $13 R-2,90$ & 416.70 & 125 & 125 & 15 & 110 \\
\hline Ripple & $13 \mathrm{R}-3,50$ & 417.80 & 145 & 145 & 15 & 130 \\
\hline Ripple & $13 \mathrm{R}-3,87$ & 418.17 & 135 & 135 & 15 & 120 \\
\hline Ripple & $14 \mathrm{R}-3,9$ & 427.09 & 50 & 50 & 246 & 164 \\
\hline Ripple & $21 \mathrm{R}-2,90$ & 493.70 & 35 & 35 & 339 & 56 \\
\hline Ripple & $21 \mathrm{R}-3,14$ & 494.44 & 270 & 270 & 315 & 325 \\
\hline Ripple & $21 \mathrm{R}-3,16$ & 494.46 & 270 & 270 & 315 & 325 \\
\hline Ripple & $21 \mathrm{R}-3,18$ & 494.48 & 270 & 270 & 315 & 325 \\
\hline Ripple & $21 \mathrm{R}-5,24$ & 497.54 & 210 & 210 & 64 & 6 \\
\hline Ripple & $21 \mathrm{R}-5,42$ & 497.72 & 15 & 15 & 64 & 311 \\
\hline Ripple & $21 R-5,66$ & 497.96 & 80 & 80 & 64 & 16 \\
\hline Ripple & $23 \mathrm{R}-3,24$ & 513.94 & 115 & 115 & 120 & 355 \\
\hline Ripple & $23 \mathrm{R}-3,64$ & 514.34 & 90 & 90 & 120 & 330 \\
\hline Ripple & $23 \mathrm{R}-4,44$ & 515.64 & 270 & 270 & 290 & 340 \\
\hline Ripple & $23 R-4,96$ & 516.16 & 260 & 260 & 290 & 338 \\
\hline Ripple & $23 \mathrm{R}-4,111$ & 516.31 & 120 & 120 & 290 & 230 \\
\hline Ripple & $23 \mathrm{R}-5,15$ & 516.85 & 55 & 55 & 115 & 300 \\
\hline Ripple & $23 R-5,38$ & 517.08 & 105 & 105 & 150 & 315 \\
\hline Ripple & $24 \mathrm{R}-1,55$ & 520.85 & 330 & 330 & 12 & 318 \\
\hline Ripple & $26 \mathrm{R}-3,114$ & 543.84 & 280 & 100 & 130 & 330 \\
\hline Ripple & $27 \mathrm{R}-2,34$ & 551.14 & 280 & 100 & 225 & 235 \\
\hline Ripple & $27 \mathrm{R}-3,133$ & 553.63 & 320 & 320 & 183 & 137 \\
\hline Ripple & $27 \mathrm{R}-4,100.5$ & 554.81 & 90 & 90 & 130 & 320 \\
\hline Ripple & $27 R-4,101.5$ & 554.82 & 110 & 110 & 130 & 340 \\
\hline Ripple & $27 \mathrm{R}-4,102.5$ & 554.83 & 80 & 80 & 130 & 310 \\
\hline Ripple & $27 \mathrm{R}-4,103.5$ & 554.84 & 110 & 110 & 130 & 340 \\
\hline Ripple & $27 \mathrm{R}-4,104$ & 554.85 & 120 & 120 & 130 & 350 \\
\hline Ripple & $27 \mathrm{R}-4,105$ & 554.86 & 100 & 100 & 130 & 330 \\
\hline Ripple & $27 R-4,108$ & 554.88 & 30 & 30 & 130 & 260 \\
\hline Ripple & $27 \mathrm{R}-4,109.5$ & 554.90 & 80 & 80 & 130 & 310 \\
\hline Ripple & $27 \mathrm{R}-4,111$ & 554.91 & 120 & 120 & 130 & 350 \\
\hline Ripple & $27 \mathrm{R}-5,121$ & 556.51 & 315 & 135 & 315 & 180 \\
\hline Ripple & $28 \mathrm{R}-1,55$ & 559.45 & 190 & 10 & 120 & 310 \\
\hline Ripple & $28 \mathrm{R}-1,57$ & 559.47 & 190 & 10 & 120 & 250 \\
\hline Ripple & $28 \mathrm{R}-1,132$ & 560.22 & 250 & 70 & 50 & 20 \\
\hline Ripple & $28 \mathrm{R}-2,83$ & 561.23 & 250 & 80 & 138 & 302 \\
\hline Ripple & 28R-2, 109 & 561.49 & 240 & 60 & 138 & 282 \\
\hline Ripple & $28 \mathrm{R}-3,132$ & 563.22 & 60 & 60 & 140 & 280 \\
\hline Ripple & $28 \mathrm{R}-3,139$ & 563.29 & 310 & 310 & 140 & 170 \\
\hline Ripple & $28 \mathrm{R}-3,139.5$ & 563.30 & 135 & 135 & 140 & 355 \\
\hline Ripple & $28 \mathrm{R}-3,140.5$ & 563.31 & 120 & 120 & 140 & 340 \\
\hline Ripple & $33 R-1,21$ & 578.51 & 110 & 110 & 220 & 250 \\
\hline Ripple & $33 \mathrm{R}-1,77$ & 579.07 & 70 & 70 & 140 & 290 \\
\hline Groove & $18 \mathrm{R}-4,31$ & & 165 & 165 & 270 & 255 \\
\hline
\end{tabular}

${ }^{a}$ Measured ripple migration direction clockwise from arbitrary marked reference frame on core lining.

${ }^{b}$ Number used qualitatively to assess normal or reverse polarity in order to determine $\pm 180^{\circ}$

${ }^{\mathrm{c}}$ Declination of magnetic north clockwise from arbitrary marked reference frame on core lining.

${ }^{\mathrm{d}}$ Restored current-ripple migration (turbidity-current flow) direction obtained from Measvector $\pm \mathrm{D}=\mathrm{Vector}$ Corr.

Figure 4 also shows the grain orientation from 16 thin sections, based on magnetic fabric measurements by Taira and Niitsuma (1986), showing that the turbidity currents transported sediment parallel to the trench axis, predominantly from the northeast (interpreted from petrographic studies). The grain orientation is based on magnetic susceptibility of inequant grain shapes in anisotropic magnetite and titanomagnetite. The maximum susceptibility is aligned in the direction of the longest axis, and the minimum susceptibility is oriented along the shortest axis. $K_{\min }$ (minimum magnetic susceptibility) defines the imbrication direction of the grains. Samples with a $K_{\min }$ direction of less than $60^{\circ}$ inclination were discarded and deformed intervals were not used, i.e., 0-200 mbsf (Leg 87 DSDP Site 582 floor of Nankai Trough, Taira and Niitsuma, 1986).

Figure 5 shows the paleomagnetically restored flow directions, based on the measurement of the current ripples, vs. depth downhole. From this graph, albeit with limited data, it can be seen that the greatest dispersion in turbidity-current flow direction appears to have occurred in the oldest part of the trench outer slope succession (i.e., from about 500-560 mbsf). In terms of paleoenvironment, this older section in the stratigraphy would correspond to the most elevated part of the trench outer slope and, therefore, the most likely zone in which to find evidence for flow collapse and flow reflection.

\section{FLOW COLLAPSE AND FLOW REFLECTION}

Unusual aspects of the turbidites include the vertical repetition of current-ripple lamination between parallel lamination, the presence of distinctive grain-size breaks, variable flow directions in a single bed, and the weakly bioturbated muddy or clayey siltstone caps. Collectively, these features suggest rapid deposition from unsteady flows that may have been deflected and/or reflected from the inner and trench outer slopes. The variable, complex, paleoflow in the outer trench is interpreted as a result of both: (1) the deceleration and collapse of axial flows such that the body of the turbidity current is deflected directly downslope, and (2) the reflection of upslope-flowing turbidity currents, from flows derived from either the Izu Collision 
A

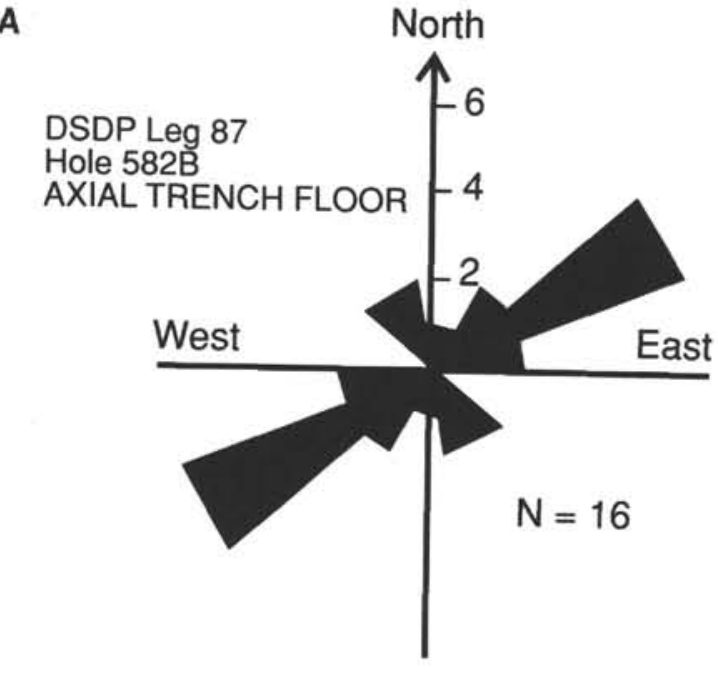

B

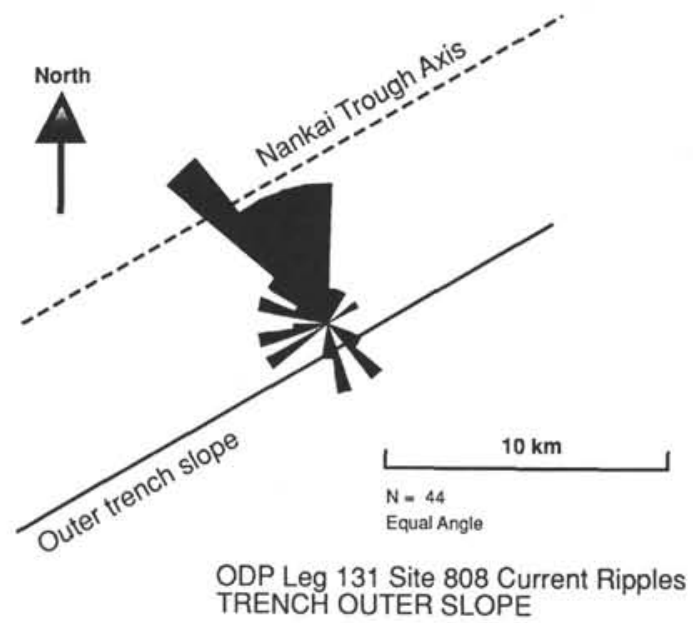

Figure 4. Rose diagram showing (A) plot of mean preferred grain orientations ( $a$ - or long axes) at DSDP Site 582, determined by fabric analysis in 16 thin-sections (these bidirectional flow indicators correlate well with magnetic fabric data and suggest a predominant paleoflow toward the southwest, down the trench axis (Taira and Niitsuma, 1986); (B) restored paleocurrents from fine-grained sandy turbidites of the trench outer slope facies, obtained from the dip azimuths of ripple cross-laminae at ODP Site 808 and reoriented using the detrital natural remanent magnetism (NRM). This is the first paleocurrent diagram to use current ripple data in the history of the Deep Sea Drilling Project and Ocean Drilling Program which began in 1968.

Zone as axial flows or the accretionary prism north of the trench back toward the trench axis as lateral flows.

The original flow directions (prior to rebound) are difficult to constrain. For example, some of the turbidity currents may have originated somewhere on the inner trench (accretionary prism) slopes and undergone a reflection of $180^{\circ}$ or simply have been deflected at smaller angles, depending upon the angle of incidence with respect to the trench outer slope. Alternatively, others may have flowed axially along Nankai Trough from the Izu Collision Zone, as suggested for the majority of the sand turbidites of Unit IIa (Taira and Niitsuma, 1986). As the flows experienced radial expansion and decelerated, the entrained bankfull parts of thick turbidity currents

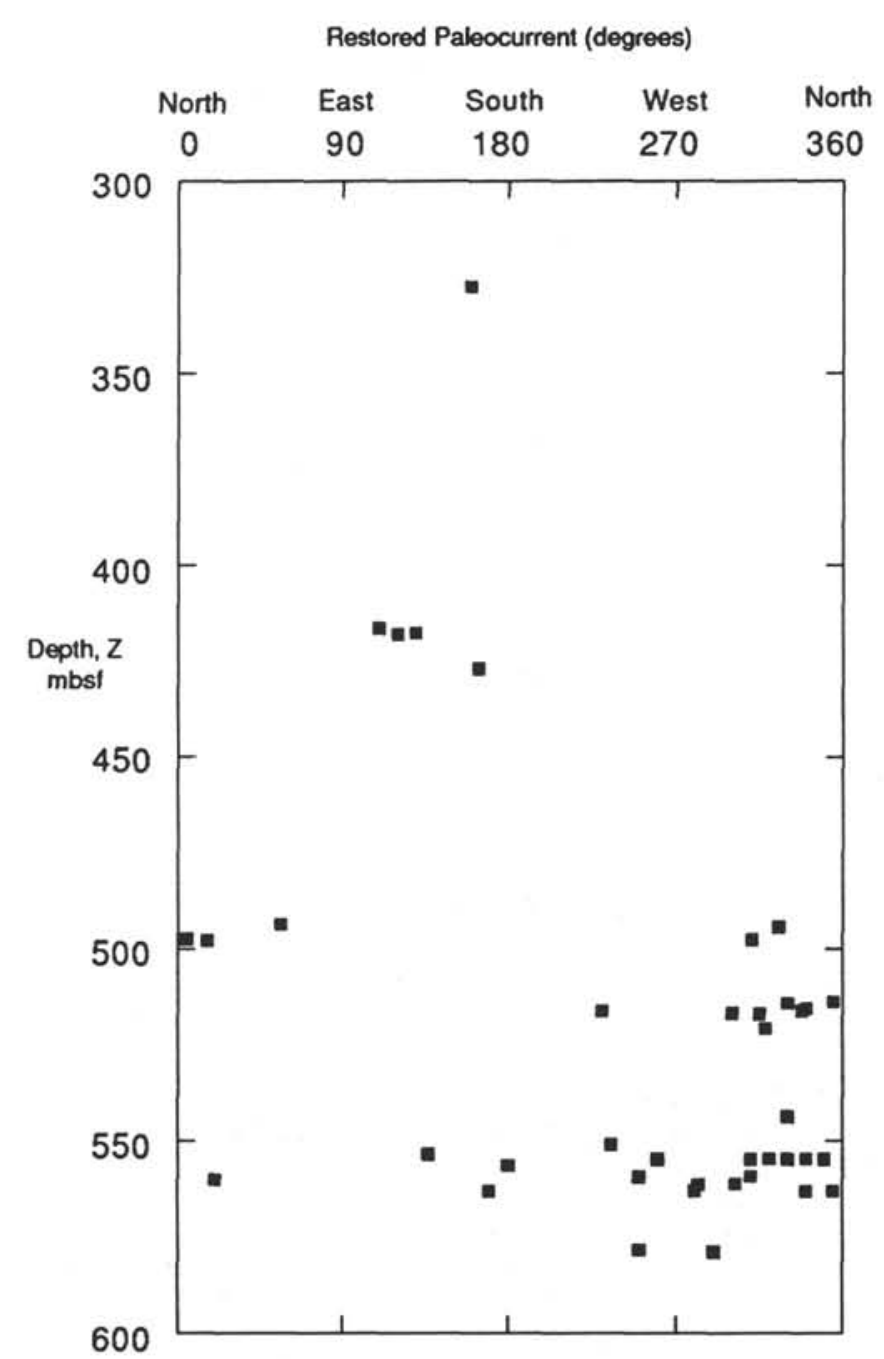

Figure 5. Paleomagnetically restored paleocurrents for Site 808 showing turbidity-current flow directions for current ripples vs. depth (mbsf). Note that the greatest dispersion in flow directions appears to be associated with the stratigraphically oldest part of the trench outer slope deposits- something that would be expected since this interval represents the topographically highest part of the trench outer slope where the propensity for flow collapse and reflection would have been greatest.

may have wedged out against the outer slope, then collapsed directly down the steepest gradients toward the trench axis. Lastly, another possibility is that oblique-upslope movement of flows onto the trench outer slope may have experienced a shift in their center of gravity associated with a momentum decay, followed by a final downslope surge.

A curious aspect of these turbidites is that many of the beds appear to show initial deposition from the collapsing or reflecting current and not from the flow which rode up the trench outer slope. A likely explanation for this is that the run-up area for those flows was not sampled in some of the beds where paleocurrents were measured, but that it was located farther northeastward, toward the sediment source.

Figure 6 is a conceptual model to explain the origin of the paleocurrent pattern caused by the collapse of axially-flowing turbidity currents, together with oblique flow deflection and orthogonal flow reflection from currents which enter the trench by lateral flow. An evaluation of the relative importance of these different source areas is beyond the resolution available in this study. 


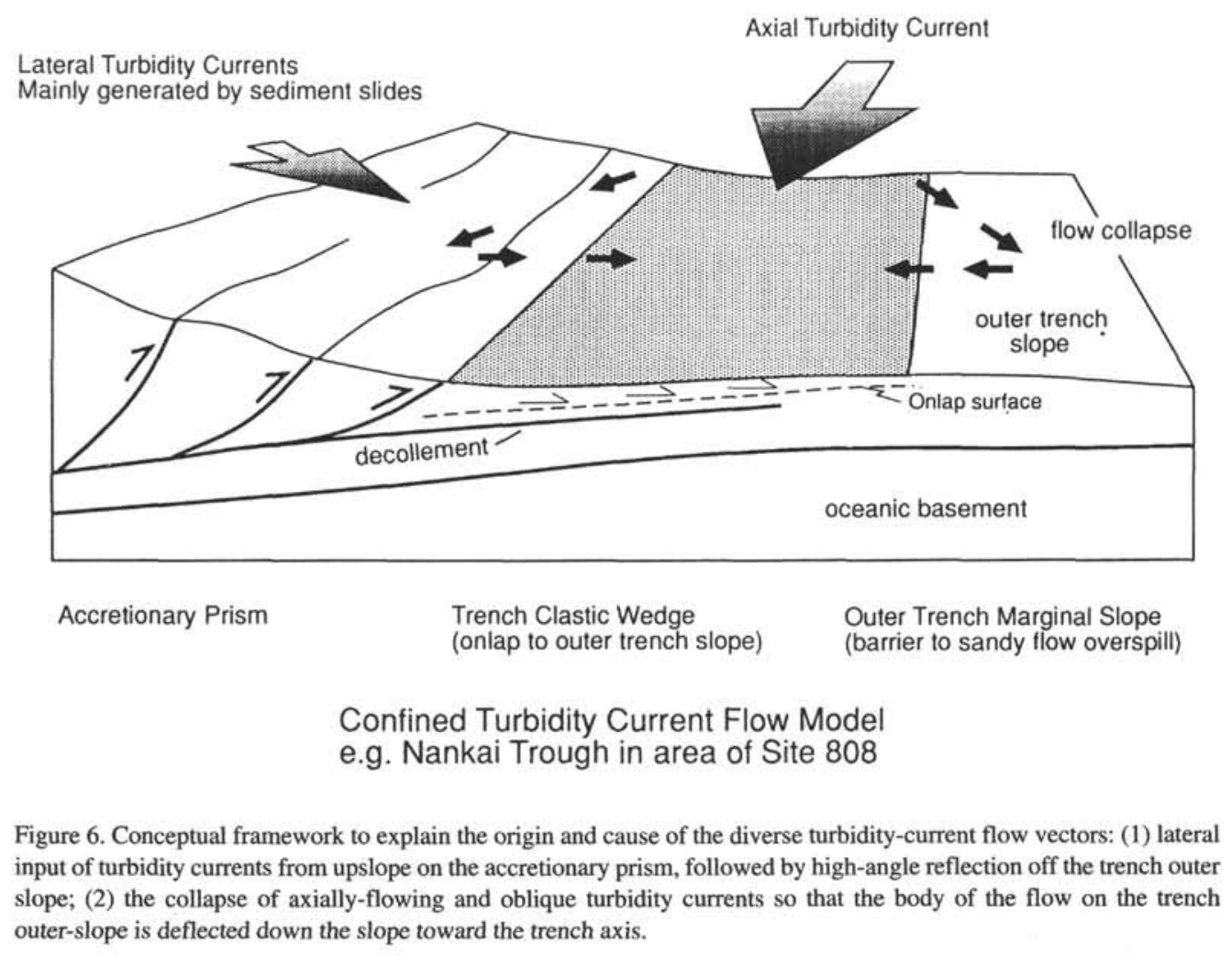

\section{CONCLUSIONS AND IMPLICATIONS FOR OTHER MODERN AND ANCIENT TURBIDITE SYSTEMS}

The paleocurrent results from the Nankai Trough, ODP Leg 131, have important implications for the interpretation of other modern and ancient linear deep-marine basin deposits. They show that caution should be exercised in inferring the provenance of turbidity currents from paleocurrent data alone. Furthermore, they highlight the complexity of flow within a linear basin such as a trench or foreland basin. Indeed, this study casts doubt on the interpretation of an oceanward continental sediment source, now subducted/subcreted, which has been invoked to explain the occurrence of terrigenous turbidites with south-to-north paleocurrents (from flute casts) in the Shimanto Belt of Japan (Kumon, 1988).

In many linear or laterally-confined turbidite systems like deepmarine trenches and foreland basins, sole structures (erosional or $E$-structures) and ripples (depositional or $D$-structures) commonly show a divergence within individual beds by up to $90^{\circ}$, e.g., the lower Paleozoic of central Ireland (Cope, 1959), the lower Paleozoic Southern Uplands (Craig and Walton, 1962, Scott, 1967), the Carboniferous of southwest England (Prentice, 1962), the lower Paleozoic Welsh Basin (Kelling, 1964), and the lower Paleozoic Oslo region (Seilacher and Meischner, 1965). This divergence is readily explicable as the result of deposition associated with flow collapse immediately following the erosional phase of turbidity current flow and, in some cases, where paleocurrent dispersion is low to moderate as a consequence of flow-meandering (Parkash and Middleton, 1970). As a turbidity current riding up a basin slope loses kinetic energy and decelerates, a process that is particularly likely with flow expansion, so the flow becomes much more sensitive to basin-floor topography and therefore develops an increasing tendency to start moving directly downslope. In other words, the turbidity current becomes more sensitive to gravitational rather than inertial forces due to the momentum changes during flow deceleration. Thus, $D$-structures like the ripplelaminated Bouma $T_{c}$ division tends to reveal the basin-floor topography, whereas $E$-structures, such as flutes and grooves, may only indicate the direction of turbidity current flow during the phase of acceleration or near-constant velocity. Current ripples have traditionally been undervalued in basin analysis, and careful measurement of ripple azimuths in ancient turbidite systems may help constrain basin shape and topography.

\section{ACKNOWLEDGMENTS}

This manuscript has been greatly improved by the critical reviews and helpful suggestions made by Drs. Gerry Middleton and Bill Normark to an earlier version of the paper.

\section{REFERENCES}

Cita, M., Beghi, C., Camerlenghi, A., Kastens, K., McCoy, F., Nosetto, A., Parisi, E., Scolari, F., and Tomadin, L., 1984. Turbidites and megaturbidites from the Herodotus abyssal plain (eastern Mediterranean) unrelated to seismic events. Mar. Geol., 55:79-101.

Cope, R.N., 1959. The Silurian rocks of the Devilsbit Mountain district, County Tipperary. Proc. R. Ir. Acad., Sect. B, 60:217-242.

Craig, D.Y., and Walton, E.K., 1962. Sedimentary structures and palaeocurrent directions from the Silurian rocks of Kircudbrightshire. Trans. Edinburgh Geol. Soc., 19:100-119.

Damuth, J.E., and Embley, R.W., 1979. Upslope flow of turbidity currents on the northwest flank of the Ceara Rise: Western equatorial Pacific. Sedimentology, 26:825-834.

Dolan, J., Beck, C., and Ogawa, Y., 1989. Upslope deposition of extremely distal turbidites: an example from the Tiburon Rise, west-central Atlantic. Geology, 17:990-994.

Edwards, D., 1991. Turbidity currents: dynamics, deposits and reversals [Ph.D. thesis]. Leeds Univ.

Kelling, G., 1964. Cross-lamination in graded bed sequences. J. Sediment. Petrol., 34:379-388.

Kumon, F., Suzuki, H., Nakazawa, K., Tokuoka, T., Harata, T., Kimura, K., Nakaya, S., Ishigami, T., and Nakamura, K., 1988. Shimanto Belt in the Kii Peninsula, southwest Japan. Mod. Geol., 12:71-96.

Moore, J.C., Watkins, J.C., et al., 1982. Facies belts of the Middle America Trench and forearc region, southern Mexico: results from Leg 66 DSDP. 
In Leggett, J.K. (Ed.), Trench-forearc Geology. Geol. Soc. Spec. Publ. London, 10:77-94.

Muck, M.T., and Underwood, M.B., 1990. Upslope flow of turbidity currents: a comparison among field observations, theory, and laboratory models. Geology, 18:54-57.

Pantin, H.M., and Leeder, M.R., 1987. Reverse flow in turbidity currents: the role of internal solitons. Sedimentology, 34:1143-1155.

Parkash, B., and Middleton, G.V., 1970. Downcurrent textural changes in Ordovician turbidite greywackes. Sedimentology, 14:259-293.

Pickering, K.T., and Hiscott, R.N., 1985. Contained (reflected) turbidity currents from the Middle Ordovician Cloridorme Formation, Quebec, Canada: an alternative to the antidune hypothesis. Sedimentology, 32:373-394.

Piper, D.J.W., von Huene, R., and Duncan, J.R., 1973. Late Quaternary sedimentation in the active eastern Aleutian Trench. Geology, 1:19-22.

Prentice, J.E., 1962. The sedimentary history of the Carboniferous in Devon. In Coe, K. (Ed.), Some Aspects of the Variscan Fold Belt: Manchester (Manchester Univ. Press), 93-108.

Scott, K.M., 1967. Intra-bed palaeocurrent variation in a Silurian flysch sequence, Kircudbrightshire, Southern Uplands of Scotland. Scott. J. Geol., 3:268-281.

Seilacher, A., and Meischner, D., 1965. Fazies-analyse im palaozoikum des Oslo-Gebeites. Geol. Rundsch., 54:596-619.
Shipboard Scientific Party, 1991. Site 808. In Taira, A., Hill, I., Firth, J.V., et al., 1991.Proc. ODP, Init. Repts., 131: College Station, TX (Ocean Drilling Program), 71-269.

Taira, A., Hill, I., Firth, J.V., et al., 1991. Proc. ODP, Init. Repts., 131: College Station, TX (Ocean Drilling Program).

Taira, A., and Niitsuma, N., 1986. Turbidite sedimentation in the Nankai Trough as interpreted from magnetic fabric, grain size, and detrital modal analysis. In Kagami, H., Karig, D.E., Coulbourn, W. T., et al., Init. Repts. DSDP, 87: Washington (U.S. Govt. Printing Office), 611-632.

Underwood, M.B., 1986. Transverse infilling of the Central Aleutian Trench by unconfined turbidity currents. Geo-Mar. Lett., 6:7-13.

, 1991. Submarine canyons, unconfined turbidity currents, and sedimentary bypassing of forearc regions. Rev. Aquat. Sci., 4:149-200.

van Andel, T.H., and Komar, P.D., 1969. Ponded sediments of the Mid-Atlantic Ridge between 22 and 23 North latitude. Geol. Soc. Am. Bull., 80:1163-1190.

Date of initial receipt: 11 November 1991

Date of acceptance: 25 June 1992

Ms 131SR-104 